\title{
The Investigation Research of Private Lending in Hui Autonomous Prefecture of Linxia, China
}

\author{
Haiying Ma \\ School of Economics, Northwest University for Nationalities, Lanzhou (730124), P.R.China, \\ Ixmahaiying8888@163.com
}

Keywords: Private lending; Hui Autonomous Prefecture; Minority regions; Linxia

\begin{abstract}
The private lending, as the one of financial form which the access to the loan capital derived from Informal financial institutions, plays the important role on the economic activity, and have a profound impact on the development of local finance. Through the roundly questionnaire survey in the Hui autonomous prefecture of Linxia to understand the present conditions, causes and purposes of the regional private lending, this paper analyze the problems arising during the development of informal capital market, and finally the paper propose the policy advice to promote the development of informal capital.
\end{abstract}

\section{Introduction}

Private lending is also called the folk credit or personal credit, and it refers the credit that provided between the resident individuals and the collective, and generally takes the mode of discussed interests and direct transaction. The formation and development of private lending in China has been a quite a long time, in recent years, with the policy adjustment of country's interest rate and the influenced by the difficulty of farmers' micro-credit loans, the private lending market became more active, and had the deepening impact on the local finance.

Hui autonomous prefecture of Linxia is located in the south central of Gansu province which lives more than two million people of 22 nationalities, such as Hui, Han, Dongxiang, Bao' An, Salar, Tu, Tibetan. Informal financing make up for the shortage of formal finance to a certain degree, and it plays a supplementary role on the development of regional economy. Informal financing satisfied the fund demand of private economy, individual business and the residents due to its simple, flexible, fast, and it also makes up the fault age of county financial system; increasing the usage efficiency of social idle funds, and promote the development of local economy, especially the non-public sectors of the economy.

The questionnaire is design for the private lending conditions in Hui autonomous prefecture of Linxia, and analyzed the income of loaner and borrower, reason of credit, and the period and interest rate of credit separately to understand the current situation and existing problems in the local informal financing. Totally, more than 500 questionnaires were sent out, covering the city, urban and rural regions. Through the form such as field research, document consulting, and news searching, the investigation is lasting for seven days. Facing to the development status of private lending in Hui autonomous prefecture of Linxia through field research, we analyzed the characteristics and existing problems in the development of informal financing in this region hoping putting forward the countermeasures, and lead the standardization development of this region's private lending.

\section{The Present Situation and Characteristics the Private Lending}

The Understanding of Private Lending. The generalized private lending refers the credit behavior without the formal financial institution in the society, it also can be called the informal finance outside the system, and the narrow sense of private lending refers credit activities between individuals, and it's pretty confusing in part. According to the judicial interpretation of Supreme People's Court: Private lending is the behavior of credit between people, citizens and legal persons, citizens and other 
organizations. These definitions are reflected some characteristics of private lending: informal, simple procedure, low cost, flexible interest rate on the high side, and high risk.

Through the investigation by questionnaire, the significant data shows that the people in Hui Autonomous Prefecture of Linxia has a very limited understanding of private lending, most people agree with personal loan belongs to the folk, then it's a type of private lending that borrow from small-scale loan company and legal person. And still have $20 \%$ of people think that borrowing from commercial banks, credit cooperatives belongs to private lending. In fact, the credit behavior from the formal financial institution is not private lending; therefore, it is ambiguous on the understanding as shown following.

Participation and the Dispute in Private Lending. The investigation showed that $51 \%$ of the respondents had never been involved in private lending, $49 \%$ of the respondents involved in private lending. It can seen from the data, the degree of participation of non-governmental financing is pretty high, the participant has a considerable scale. The survey data showed that $92 \%$ of respondents think that the disputes has been happened in the private lending, and only $8 \%$ of respondents think that there is no dispute in this activity.

The Active Characteristics of Loanees and the Loaners. During the survey, we found that the people who was loanee is in the majority, and it accounted for $59 \%$. the people who was loaner is in the minority, and it accounted for $41 \%$. The $48 \%$ of the loanees would borrow from relatives and friends, and the people who choose to lend money to friends and relatives accounted for $31 \%$ of the total. We think the reason for the choices are the trust among Chinese is based on relationship, blood relationship, and friendship, people tend to borrow from their relatives, friends, because they know each other, there is a high credit between each other, and it is more likely to success; of course, there still has some people to choose borrow from informal intermediaries, and it accounted for $28 \%$ of the total, the people who lend to intermediaries accounted for $31 \%$. And according to the visit, the most of alleged informal intermediaries are small local organizations, and loaning from the informal intermediaries has a simple procedure, and a low cost. The people who loan to informal intermediaries thinks the interest is higher than bank or deposit financial institutions, etc, and can get some interests from the spare money, what's more, this kind of credit behavior belong to the short-term and medium-term loans, there almost have no long-term loan, therefore, it is safe and reliable in the case of have certain formalities; but the people who borrow from loan corporation accounts for only $16 \%$, the people who lend to loan corporation accounts for $25 \%$, this kind of loan company have complicated procedures and high threshold, usually need some guarantee to borrow, and it also have certain stipulation of guarantee, and most of the loan behavior belong to the mid-term and long-term lending, considering the basic situation of Hui Autonomous Prefecture of Linxia, we think such loan is minority in the local. Though it is, it could get considerable earnings in this way; of course, there is some people choose other way of financing, but accounts for only $8 \%$. The people who lean to other credit also accounts for only $13 \%$.

The Agreement Form and Reason of Choosing the Private Lending. In this investigate, $30 \%$ of the respondents tended to choose oral agreement, $70 \%$ of the respondents would choose to sign a written loan agreement. Can be seen from the data, the legal consciousness of both sides in private lending is not very strong, it tends to produce more debt disputes for the small percentage of the oral agreement.

The investigate shows that $47 \%$ of borrowers choose it cause of the simple procedure of informal financing, convenient and in time, while $20 \%$ of borrowers think the cost is low, and then is its longer term and tax avoidance, only $4 \%$ of borrowers think informal financing can be better used to reasonable tax avoidance.

The Analysis of the Disadvantage in Private Lending. In the investigation, the participants of private lending think the interest rates of private lending and default risk is too high, and the borrowing is not standard, $16 \%$ of respondents believe that the legal system is not perfect, only $9 \%$ of borrowers think informal financing increased the burden of the borrower. 


\section{The Cause Analysis of Activity from Private Lending}

The Needs of Economic Development. With the development of commodity economy and the reform and opening up, Chinese private lending gradually developed. The lending standard of formal financial institutions is high, so it cannot fully meet the demand of social capital, and the imbalances of capital supply and demand stimulate the development of the private lending. Because China has a very strong sense of kinship, and mutual understanding and trust has been established between friends and relatives, which makes private lending established on the basis of individual credit gradually active, and the lower transaction costs has been favored by the borrower. So, despite the private lending has not obtain legal status in China, it will boom with the development of economy.

The Simplicity of Procedure. In order to ensure the stability and safety of the financial system, almost all formal financial institutions will strictly control lending, deposits-loans surplus in each commercial banks are pretty big, the problem of loan is difficult has gradually become a social problem. Whether in the production and operation, or in the event in life such as weddings, children education, build or cure, etc. The people in Linxia city undertook the great fund pressure, they need borrow, and nearly half of the informal financing needs shows its importance. It is because of the informal financing has its own unique advantages that allows it complement the blank of the formal financial financing market. The formal credit has the advantage of simple and convenient procedure, small amount, flexible operation, and long deadline, which makes the small enterprises, individual businesses and farmers adjust the founds more easily. Compared with the bank credit, the private lending avoid the tedious credit check procedure, don't need higher guarantee. At the same time, some private lending occurred among friends and relatives, interest-free loans are also common, this way of low cost of financing, also have the necessity of its existence.

The Assist of Private Lending. In the survey, we found that the large part of borrowers in informal financing is informal intermediary. The intermediary link capital demanders to providers, but they are different from small loan companies, low risk and high yield make it a vast living space. In the assistance of informal intermediary, borrowers can fully access information to each other, avoid the determination in information asymmetry, and also accelerated the flow of social capital, solved the problem of lenders lack of professional knowledge and law, optimize the allocation of resources. The existence of informal intermediaries make substantial basis for the prosperity of the folk financing.

The Guidance of Credit Environment. At present, Chinese commercial Bank lending capacity cannot fully meet the demand of social capital; part of the commercial bank loan has been negative, high loan approval condition and the complicated approval system added to the problem. This series of credit macro environment increased the difficulty of financing, make it impossible for small and medium-sized enterprises, individual businesses and farmers to get loan. As for the farmers, small and medium-sized enterprises, individual household who in urgent need of money and without high quality guarantee is hard to borrow money. In the face of such situation, private lending began to gradually come into being. In some way, private lending is a supplement to the formal financial, and it is the credit environment since continuously guide and development.

The Driving Force of Benefit. At present, Chinese financial market is not developed, for the individual with limited funds and without financial products investment philosophy; it is a good choice to lend money from informal borrowing intermediary. The informal lender, can get higher than the bank deposit interest income, and avoid the high risk of securities investment. Some speculators also raise a larger capital to invest and make a profit through private lending.

The Needs of the Small-medium Sized Enterprises. For private small and medium-sized enterprises in China, the enterprise is at the early stage of development, with the huge capital demand and thin margins, they would choose the informal financing to improve the company's financial leverage and reasonable tax avoidance, so they could expand the size of the power of life. However, the threshold of financing institution such as commercial bank is high, and come into the Growth Enterprises Market is difficult, so, the private lending is become their better choice. 
Poor of Legal and Financial Supervision. Most private lending is very hidden, and the supervision is weak, and in the some opinions of Supreme People's Court borrowing case law to private credit norms is also very limited. Therefore, private credit has its own development space and flexibility.

\section{The Problems Existing in the Development of Private Lending}

The Borrowing is not Standard, and the Interest Rate is High. Private lending procedures are simple, but it lack of necessary management and support by laws and regulations, it is blind, not normative, unstable, what's more, it is easy to cause borrowing debt disputes between the two sides and have a negative impact to the society. They recover loan by violence once private lending in the event of not repaying debt and it brings danger to the both sides. There arise some dun company with part of the loans using for gambling, drugs and other serious violations, a bigger threat to society.

The Informal Intermediary is not Standard. At present, different regions in China appeared the behavior of informal intermediary deceives the borrowing individual frequently, and this dispute over obligation is common in Hui Autonomous Prefecture of Linxia. Part of the informal intermediaries defrauds the lender who has idle funds, and they cannot preserve the safety of the funds. High-interest informal lending interest rates, once the interest rates four times higher than bank interest rates, borrowing behavior are illegal, and not protected by law.

High Default Risk and Illegal Fund-raising Fraud. Due to the lack of folk financing and financial regulation by law, there might be a lot of legitimacy and even illegal behaviors, and it does serious harm to the social order and social stability. It is difficult to control that the investment direction of informal financing accumulation fund, some still have a tendency to violate national industrial policy, and it is easily to lead the problems such as illegal fund-raising fraud. Based on personal credit of the informal borrowing behavior is lack of financial guarantee, the risk of default is more higher than other financing ways, the debt disputes also is unable to avoid.

Contributing to the Usury and destroying the normal financial order. Interest rates of many small and medium-sized enterprises or individuals borrowed money form informal capital are generally higher, and it is up to 3-4 times higher than the same period bank interest rates. High interest rates, on the one hand, increase the operator's financial burden, form a vicious circle, and it's bad for the healthy development of private economy and individual economy; on the other hand, it leads to the existence of usury, produced a part of the renter class in society.

The Difficulty of Credit Risk to control. Firstly, the most basic of credit system is relatives, friends, acquaintances, but with the development of market economy, borrowing range has been far beyond the range of this relative network, so this kind of trust mechanism becomes more and more fragile, prevention for risk is becoming more and more unreliable. The second is the speculation, denationalization factors further raised lending rates, increased the risk of default, to a certain extent, the worse is it could bring chain reaction easy once the bubbles burst.

The Imperfect Legislation behind the Social Practice. Relevant laws and regulations refer to general rule of civil law, property law, guarantee law, contract law, criminal law and suppress method for Illegal financial institutions activities, general rules and other laws and regulations, exposed imperfection of fragmentation, and make private lending wandering in the gray area outside the formal financial system. Then, reasonable and normal private lending has mixed up with illegal fund-raising, fraudulent fund-raising and other illegal and criminal activities, there is no clear legal guidelines to distinguish, free between legal and illegal; what's more, there is almost no judicial guidance for the all kinds of new forms and patterns in private lending.

Regulation far away from the Designated Position. Private lending would not be supervised by the special regulators. So the slowly expansion and modification does not cause the government's strong concern at first, each time only when the situation is relatively serious will government take strict measures to punish. Released in March 2011"Interim Procedures for financing guarantee company management is formulated. The ministry of finance, Ministry of Commerce, People's Bank 
of China, seven departments' regulations is too diverse to make fuzzy real supervision subject, daily supervision, in fact, is in the vacuum state.

Private lending is a kind of underground finance, its non-public mode of operation make it unclear that the capital source and flow direction, the overall lending interest rates, credit risk, such as information, so, it is hard to supervise. In addition, with the innovation of the mode and expansion of the scope of business those years, there is no such legal guidance, make it almost in a blank area of regulation.

\section{Countermeasures and Suggestions}

For the government and the financial supervision and regulation department, it should formulate reasonable private lending rules and method and guide the private lending practices correctly. At the same time, the government should improve the investment environment to encourage and guide non-governmental capital investment directly strengthening the management of interest rate, regulate private lending further. The Financial mechanism should make efforts to improve service levels providing residents with simple and quick deposit service by modern technology. As for the individual, they should choose legal private lending intermediary mechanism. Small and medium-sized enterprises should be careful to borrow money. During the process of small and medium-sized enterprises' informal financing, they should consider the company's financial situation cautiously and use the money in a planned way to prevent the debt crisis.

\section{Acknowledgements}

This work was supported by the Fundamental Research Funds for the Central Universities of Northwest Minzu University (Grant No. 31920170127).

\section{References}

[1] Cao Xiaochun, On Islamic Finance and its Introduction in Ningxia, Journal of Beifang Ethnic University. 14 (2009) 52-54.

[2] Feng Lulu, Contradiction of Religion and Development-Discussion on the Theory, Culture and Practical Conflict of Islam and Financial Globalization, Social Sciences in Ningxia. 4 (2004)65-69.

[3] Ju Qiang, A new upsurge and development of world financial system, International financial research. 11 (2008)78-81.

[4] Imam P., and Kangnik, Islamic banking: how has it spread, IMFN Working Paper, Sep, 2010.

[5] Wu Yonggui,. The International Financial Movements in Postwar Period, World Religious Study. 2 (1989)123-129.

[6] Xu Liping, An analysis of Islamic financial system in Malaysia, Southeast Asia Research. 1 (2004)112-128.

[7] Zhang Xiaofeng, Research to Introduce Islamic Financial Operation Mode-An Example of Ningxia, Economic research. 11(2009)97-99.

[8] Zhao Zhonglong, Islamic finance, law and economics analysis. Journal of academic exchanges. 8(2014)112-121

[9] Lulu Feng, Rethinking on Islamic economic modernization problem. Journal of Ningxia Social Sciences. 6(2011)6-15.

[10] Zhang Ruiliang, Reference and development of Islamic finance in China. Journal of Research in the Arab World. 1(2012)16-26. 